\author{
Mateusz Sobiech \\ Uniwersytet Marii Curie-Skłodowskiej w Lublinie \\ ORCID: 0000-0003-4186-9266
}

\title{
Pasja czy biznes? Wizerunek amatorskich klubów piłkarskich w mediach społecznościowych
}

\begin{abstract}
Streszczenie
W artykule przedstawiono wyniki badań przeprowadzonych w listopadzie i grudniu 2019 roku, dotyczących zjawiska kreowania wizerunku w mediach społecznościouych przez amatorskie kluby piłkarskie. Posługując się metodą analizy zawartości mediów, zweryfikowano hipotezę badauczą, zgodnie z którą uspółcześnie funkcjonowanie nieprofesjonalnych klubów piłkarskich determinuje już nie tylko pasja do futbolu, lecz także możliwości biznesowe. Na podstawie badań ustalono, że aktywność podmiotów o charakterze non-profit (jakimi są amatorskie kluby piłkarskie) w mediach społecznościowych może generować dochody finansoue. Wnioski uynikające z przeprowadzonej analizy pozwoliły na określenie celowości, możliwości oraz efektywności procesu komunikacji wizerunkowej w nieprofesjonalnym futbolu. Ponadto autor artykułu prezentuje specyfikę amatorskich klubów piłkarskich przez pryzmat ich wizerunku oraz procesu kreowania go za pomocą mediów społecznościouych.
\end{abstract}

Słowa kluczowe: media społecznościoue, nowe media, sport amatorski, wizerunek, analiza mediów.

\section{Passion or business? The image of amateur football clubs in social media}

Abstract

The article is an attempt to present the results of research conducted on November and December of 2019 on the process of image creation in social media by amateur football clubs. The author could verify the research hypothesis by using the method of media content analysis. He proved that today's functioning of non-professional football clubs is determined not only by passion for football, but also by business opportunities. The research established that the activity of non-profit entities (such as amateur football clubs) in social media may generate financial income. The conclusions of the analysis made it possible to determine the advisability, possibilities and effectiveness of the process of image communication in non-professional football. Additionaly, the article presents the specificity of amateur football clubs, through the prism of their image and the process of creating it in social media.

Keywords: social media, new media, amateur sports, image, media analysis. 


\section{Wprowadzenie}

Współcześnie piłka nożna, dzięki technologii mediów cyfrowych, stała się sportem globalnym. Dotyczy to zarówno jej profesjonalnego, jak i amatorskiego wydania. Czasy, kiedy transmisje ze stadionów piłkarskich były dostępne jedynie za pośrednictwem telewizji lub radia, bezpowrotnie minęły. Media społecznościowe, takie jak Facebook czy Twitter, stały się istotnym przekaźnikiem treści związanych z organizacjami oraz klubami piłkarskimi na świecie. W XX wieku wiadomości oraz relacje futbolowe rozpouszechniane w ogólnopolskich mediach w zdecydowanej większości obejmowały tylko rozgrywki profesjonalne, jak na przykład transmisje meczów Premier League ${ }^{1}$, Mistrzostu Świata czy rozgrywek UEFA Champions League ${ }^{2}$. W tym samym okresie materiały o amatorskich klubach piłkarskich były rozpouszechniane głównie w mediach regionalnych i lokalnych, w prasie (np. „Gazeta Morąska”), radiu (np. Radio Olsztyn) czy telewizji (np. Top-Sat Telewizja Kablowa). Wraz z dynamicznym rozwojem nowych technologii oraz upowszechnieniem dostępu do internetu, treści związane z nieprofesjonalnymi klubami piłkarskimi zaczęły pojawiać się w mediach cyfrowych w samej końcówce XX wieku³. Zdaniem badaczy uszystkie profesjonalne kluby piłkarskie w Polsce realizują różne strategie biznesowe, relacyjne (behawioralne) i funkcjonalne, których zadaniem jest między innymi poprawa wizerunku. Do głównych założeń właściwego funkcjonowania zespołów zawodouych, w przeciwieństwie do drużyn nieprofesjonalnych, należy na przykład generowanie zysków finansowych, co umożliwia między innymi ułaściua autokreacja własnego wizerunku ${ }^{5}$. Kontaminacja słów „wizerunek” oraz „amatorski klub sportowy” wydaje się więc oksymoronem. Obserwacja działalności wizerunkowej polskich drużyn piłkarskich, posiadających status klubów nieprofesjonalnych, daje podstawy, by stwierdzić, że public relations, promocja czy reklama znajdują zastosowanie również w ich działalności.

Celem artykułu jest przedstawienie specyfiki amatorskich klubów piłkarskich, przez pryzmat ich wizerunku oraz procesu kreowania go za pomocą mediów społecznościouych. Badania w obrębie tej problematyki stanowią punkt uyjścia do określenia celowości, możliwości oraz efektywności procesu komunikacji wizerunkowej w nieprofesjonalnym futbolu. Ponadto umożliwiają zdefiniowanie jego znaczenia w strategii

\footnotetext{
${ }^{1}$ Najuyższa w hierarchii klasa męskich ligowych rozgrywek piłkarskich w Anglii, będąca jednocześnie najuyższym szczeblem centralnym (I poziom ligowy). Zmagania w jej ramach toczą się cyklicznie (od sierpnia do maja) i przeznaczone są dla 20 najlepszych krajouych klubów piłkarskich. Jej triumfator zostaje Mistrzem Anglii, zaś najsłabsze drużyny są relegowane do Championship (II ligi angielskiej).

${ }^{2}$ Klubowe rozgrywki piłkarskie, przeznaczone dla najlepszych męskich drużyn klubouych (zajmujących czołowe miejsca w europejskich ligach krajouych) oraz rozgrywane na europejskich stadionach. Są to najbardziej prestiżowe klubowe zmagania piłkarskie w Europie.

${ }^{3}$ D. Baran, Internet $w$ Polsce [w:] Polski system medialny 1989-2011, red. K. Pokorna-Ignatowicz, Oficyna Wydawnicza AFM, Kraków 2013, s. 75-92.

${ }^{4}$ H. Mruk, Marketing sportowy - teoria i praktyka, Impact Consulting, Poznań 2004, s. 21.

5 S. Fullerton, Sports marketing, McGraw-Hill, Maidenhead 2009, s. 48-49.
} 
działań public relations. Do istotnych założeń artykułu należy znalezienie odpowiedzi na następujące pytania badaucze:

1. Jak często nieprofesjonalne kluby piłkarskie publikują treści w mediach społecznościouych?

2. Jakie wyniki osiągają posty amatorskich klubóu piłkarskich?

3. Czy kluby wchodzą w interakcję z fanami?

Do innych celów artykułu należy ustalenie, czy aktyuność w mediach społecznościowych umożliwia amatorskim klubom piłkarskim (czyli podmiotom ukierunkowanym na działalność non-profit) generowanie dochodów finansouych. Ponadto badania umożliwią zueryfikowanie dwóch hipotez badawczych. Zgodnie z pieruszą założono, że istnienie amatorskich klubów piłkarskich nie determinuje już tylko pasja do futbolu, lecz także aspekt biznesouy. Według drugiej przyjęto zaś, że u okresie przeruy zimowej spada aktywność amatorskich klubów piłkarskich w mediach społecznościowych. Przedmiotem analizy były przekazy zuiązane z autokreacją wizerunku, generowane przez polskie amatorskie kluby piłkarskie. Głóunym obszarem tego rodzaju działalności były media społecznościoue. Spośród wiodących portali społecznościowych na świecie ${ }^{6}$ wyselekcjonowano dwa najpopularniejsze kanały mediów społecznościowych w polskiej nieprofesjonalnej piłce nożnej, którymi są Facebook oraz Twitter. Wstępna analiza zebranego materiału badawczego uykazała, że oba uspomniane kanały mediów społecznościouych mają zasadnicze znaczenie w strategiach komunikowania polskich amatorskich klubów piłkarskich. Okres badań objął listopad oraz grudzień 2019 roku, czyli miesiące, w których odbywają się rozgryuki piłkarskie w Polsce (listopad) oraz trua przerwa zimowa (grudzień). Warto zauważyć, że wybór tych miesięcy służy zueryfikowaniu jednej z hipotez badawczych. Według raportu opracowanego w 2017 roku przez Główny Urząd Statystyczny w Polsce działa 14858 klubów sportowych? . Niemal połowa z nich (7382) to sekcje piłkarskie. Spośród wszystkich drużyn uczestniczących w oficjalnych rozgrywkach piłki nożnej w Polsce dokonano podziału, bazując na podstawie prawnej ${ }^{8}$, na kluby profesjonalne, półprofesjonalne oraz nieprofesjonalne. Spośród klubów amatorskich, zuanych również nieprofesjonalnymi, autor dobrał próbę badawczą, wybierając trzy kluby o największej popularności w serwisie Facebook oraz Tuitter.

Artykuł jest wynikiem badań zarówno ilościouych ${ }^{9}$ (analizie poddano między innymi liczbę reakcji internautów), jak i jakościouych ${ }^{10}$ (zbadano poziom merytorycznej dyskusji w komentarzach). Z uwagi na określony cel badań, jako główną metodę

\footnotetext{
${ }^{6}$ M. Kuchta-Nykiel, 15 najpopularniejszych portali społecznościowych na świecie, https:// socialpress.pl/2018/06/15-najpopularniejszych-portali-spolecznosciouych-na-swiecie (dostęp: 2.12.2019).

${ }^{7}$ Główny Urząd Statystyczny, Kultura fizyczna w Polsce w 2016 r., https://stat.gov.pl/obszary-tematyczne/kultura-turystyka-sport/sport/kultura-fizyczna-w-polsce-w-2016-r-,12,1.html (dostęp: 1.12.2019).

${ }^{8}$ Ustawa z dnia 25 czeruca 2010 r. o sporcie (Dz. U. 2014 r., poz. 715).

${ }^{9}$ E. Babbie, Badania społeczne w praktyce, Wydawnictuo Naukowe PWN, Warszawa 2019, s. 340-397.

${ }_{10}$ Ibidem.
} 
badawczą przyjęto analizę zawartości mediów ${ }^{11}$. Zdaniem Bernarda Berelsona ten sposób prowadzenia badań gwarantuje obiektywizm, który dowodzi, że badania zostały przeprowadzone tak, aby inny badacz uzyskał $w$ nich analogiczne rezultaty. W opinii amerykańskiego naukouca systematyczność jest związana z jasnym, jednoznacznym oraz wynikającym z obiektywnych przesłanek doborem próby badawczej. Powinno ją cechować założenie dotyczące określenia przedziału czasowego oraz uyboru kryteriów, na podstawie których zostanie przeprowadzone badanie ${ }^{12}$. Literatura naukowa poruszająca problematykę wizerunku w piłce nożnej zawiera wiele publikacji anglojęzycznych, wśród których można wymienić takich badaczy, jak Sue Bridgewater, Philip Kotler czy Sam Fullerton. W skład ich dorobku naukowego wchodzą publikacje dotyczące między innymi budowania świadomości marki w klubie sportowym, marketingu w sporcie, zarządzania klubem sportowym czy aktywnością podmiotów sportowych w mediach społecznościourych. W Polsce $w$ tej tematyce na szczególną uwagę zasługują publikacje Henryka Mruka, Ryszarda Panfila, Andrzeja Sznajdera oraz Zygmunta Waśkouskiego. Wszyscy wymienieni naukoucy, zarówno polscy, jak i zagraniczni badali zagadnienia zuiązane ze sferą marketingu i public relations $\mathrm{w}$ sporcie profesjonalnym.

Przegląd literatury przedmiotu wskazuje, że brakuje opracowań dotyczących budowania wizerunku w amatorskiej piłce nożnej. Za jedną z najbardziej pokrewnych tematycznie publikacji można uznać artykuł nowozelandzkich badaczy Scotta Robinsona oraz Adriana France'a ${ }^{13}$, którego celem jest porównanie marketingu u sporcie amatorskim oraz zawodowym. Z uwagi na specyfikę sportu w Nowej Zelandii, gdzie piłka nożna jest dyscypliną niszową, a sportem narodowym są rugby, uspomniana publikacja nie analizuje jednak zjawiska autokreacji wizerunku amatorskich klubów piłkarskich.

\section{Systematyka klubów piłkarskich oraz ich kibiców}

Kluby sportowe mogą przyjmować dowolną formę organizacyjno-prawną, uwzględniając założenie, zgodnie z którym w świetle prawa będą postrzegane jako osoby prawne. Według artykułu trzeciego Ustawy o sporcie działalność sportowa jest prowadzona przede wszystkim w formie klubu sportowego, który może funkcjonować w ramach następujących form prawnych:

- spółki akcyjnej;

- spółki z ograniczoną odpowiedzialnością;

- stowarzyszenia rejestrowanego;

- fundacji;

- spółdzielni ${ }^{14}$.

${ }_{11}$ B. Berelson, Content analysis in communication research, The Free Press, New York 1952, s. 18.

${ }^{12}$ Ibidem.

${ }^{13}$ S. Robinson, A. France, Comparing sports marketing of amateur team sports to professional team sports, „New Zealand Journal of Applied Business Research” 2011, nr 1(9), s. 47-61.

${ }^{14}$ Ustawa z dnia 25 czeruca 2010 r. o sporcie (Dz. U. z 2014 r., poz. 715). 
Klub piłkarski jest takim rodzajem organizacji sportowej, którego działalność polega na uczestnictuie $\mathrm{w}$ rozgrywkach piłkarskich, organizowanych przez odpowiednią dla jego lokalizacji federację lub związek. Profesjonalne kluby piłkarskie często są jedynie sekcjami większego klubu sportowego (np. Cetralny Wojskowy Klub Sportouy Legia Warszawa), natomiast drużyny amatorskie u zdecydowanej większości przypadków są jednosekcyjnymi klubami występującymi w rozgrywkach piłkarskich. Każdy klub piłkarski zarejestrowany u Polskim Zuiązku Piłki Nożnej (PZPN) bierze udział w rozgrywkach ligowych (np. IV liga) lub pucharowych (np. Wojewódzki Puchar Polski) organizowanych pod egidą PZPN (rycina 1).

\begin{tabular}{|c|c|}
\hline Poziom & Nazwa szczebla rozgrywkowego \\
\hline 1. & Ekstraklasa (16 zespołów) \\
\hline 2. & I Liga (18 zespołów) \\
\hline 3. & II Liga (18 zespołów) \\
\hline 4. & III Liga (72 zespoły) \\
\hline 5. & IV Liga (337 zespołów) \\
\hline 6. & Klasa okręgowa (928 zespołów) \\
\hline 7. & A Klasa (1820 zespołów) \\
\hline 8. & B Klasa (2282 zespoły) \\
\hline 9. & C Klasa (242 zespoły) \\
\hline
\end{tabular}

Rycina 1. System ligouy piłki nożnej u Polsce

Źródło: opracowanie własne na podstawie danych zawartych w oficjalnym serwisie rozgrywek ligouych PZPN wuw.laczynaspilka.pl (dostęp: 10.12.2019).

Na podstawie treści Ustawy o sporcie systematykę klubów sportowych (róunież piłkarskich) determinuje status zrzeszonych w nim osób. W Polsce uyróżniamy następujące rodzaje klubów sportouych:

- profesjonalne (zawodowe) - sportowe spółki akcyjne;

- półprofesjonalne (półzawodowe) - sportowe spółki akcyjne lub stowarzyszenia kultury fizycznej;

- nieprofesjonalne (amatorskie) - stowarzyszenia kultury fizycznej ${ }^{15}$.

Klasyfikacja u ujęciu prawnym to nie jedyny rodzaj podziału przedsiębiorstu, organizacji oraz klubów sportowych. W nauce istnieją także inne typy systematyzacji podmiotów o takim charakterze. Andre Richelieu oraz Frank Pons, francuscy badacze problematyki wizerunku w sporcie, wyróżniają cztery fazy rozwoju przedsiębiorstu sportouych $^{16}$ :

- marka lokalna (np. MKS Avia Świdnik, ZKS Izolator Boguchwała);

- marka regionalna (np. KS Karpaty Krosno, OKS Stomil Olsztyn);

15 Ibidem.

16 A. Richelieu, F. Pons, Toronto Maple Leafs vs Football Club Barcelona: how two legendary sports teams built their brand equity, „International Journal of Sports Marketing \& Sponsorship” 2006, nr 3, s. 79-98. 
- marka narodowa (np. CWKS Legia Warszawa, TS Wisła Kraków);

- marka globalna (np. FC Barcelona, Real Madryt).

Inny rodzaj kategoryzacji sportowych spółek akcyjnych lub stowarzyszeń kultury fizycznej proponuje Ryszard Panfil. Według polskiego badacza można wyróżnić trzy fazy rozwoju klubu sportowego:

- faza rozwoju społecznego;

- faza rozwoju publicznego;

- faza rozwoju rynkowego ${ }^{17}$.

Systematyzacja sektora sportu obejmuje nie tylko kluby sportowe, lecz także widzów sportowych przedsięwzięć. Przydzielenie kibica do konkretnej kategorii warunkują motyuy będące podstawą zainteresowania się przez niego danym klubem lub dyscypliną sportową ${ }^{18}$. Wśród przyczyn wpływających na zainteresowanie piłką nożną przez kibiców teoretycy zajmujący się tą problematyką wymieniają: pozytywny stres, wzmacnianie własnej wartości, zaspokojenie potrzeby rozrywki, aspekt ekonomiczny (hazard), element estetyki futbolu, możliwość przynależności do grupy oraz odskocznia od życia codziennego ${ }^{19}$.

Zygmunt Waśkouski porównuje natomiast czynniki decydujące o byciu kibicem do zaspokajania potrzeb określonych w modelu Abrahama Maslowa ${ }^{20}$. Według badacza widzowie meczów piłkarskich zaspokajają potrzeby fizjologiczne (np. uspólne spożywanie alkoholu), bezpieczeństua (ograniczanie się do oglądania meczów u telewizji), społeczne (bycie częścią grupy, utrualanie określonej tożsamości), uznania (naśladowanie innych uczestników widowiska) oraz samorealizacji (wzorowanie się na swoich piłkarskich idolach). Kibic klubu profesjonalnego oraz amatorskiego to często ta sama osoba, ponieważ nie istnieje żadna teoria ani przepis, mówiący o wyłączności do bycia fanem tylko jednego zespołu.

W tym miejscu należy nadmienić, że kibice z miast liczących do 20 tysięcy mieszkańców lub ze usi często jako swój ulubiony klub najpierw wskazują drużynę ze suojej okolicy, a dopiero później klub o znaczeniu narodowym lub globalnym. Potwierdzają to wyniki badań Mateusza Brzeźniaka, który pokusił się o próbę charakterystyki polskich kibiców piłkarskich ${ }^{21}$. Badacz udostępnił w internecie ankietę, której respondentami byli obserwatorzy oficjalnego profilu klubu Pogoń Szczecin w portalu Facebook. W kontekście związku tego badania z amatorskimi klubami sportowymi istotną zmienną w badaniu było miejsce zamieszkania respondentów (por. rycina 2).

\footnotetext{
17 R. Panfil, Zarządzanie produktem klubu sportowego, Wyższa Szkoła - Edukacja w Sporcie, Warszawa 2004, s. 19-48.

18 S. Bridgewater, Football brands, Basingstoke, Palgrave 2010, s. 87-94.

19 D.L. Wann, N.R. Branscombe, Sports fans: Measuring degree of identification with their team, „Sports fans: Measuring degree of identification with their team. International Journal of Sport Psychology" 1993, nr 24, s. 6-27.

20 Z. Waśkouski, Zachowania kibiców jako nabywców oferty uskugowej klubu sportowego, „Marketing i Rynek” 2010, nr 4, s. 21-15.

${ }_{21}$ M. Brzeźniak, Budowanie świadomości marki w klubie sportowym, Katedra, Gdańsk 2017, s. $150-177$.
} 


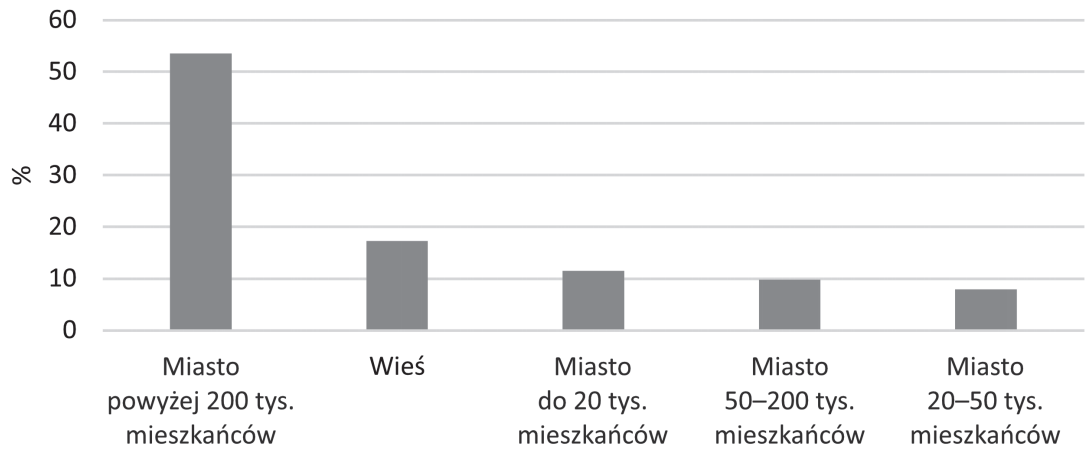

Rycina 2. Podział polskich kibiców piłkarskich ze względu na miejsce zamieszkania Źródło: opracowanie własne na podstawie M. Brzeźniak, Budowanie świadomości marki w klubie sportowym, Katedra, Gdańsk, 2017, s. 156.

Do zamiarów autora badania należało znalezienie odpowiedzi na wiele pytań, będących fundamentalną kwestią w rozuażaniach na temat procesu kreowania wizerunku przez kluby piłkarskie. Odpowiedzi na jedno z nich bezpośrednio umożliwiają określenie motywów kibicowania nieprofesjonalnym klubom piłkarskim. Na pytanie „Jakiemu klubowi kibicujesz?", spośród 17 możliwych odpowiedzi ankietowani najczęściej uskazywali Pogoń Szczecin (79\%). Drugie miejsce zajęła Legia Warszawa (6,9\%), na trzecim zaś miejscu znalazła się opcja „inny klub” (3,9\%). Istotnym jest fakt, że w przypadku uyboru ,innego klubu” ankietowani mogli dopisać klub, któremu kibicują. Wśród nich pojawiło się wiele klubów amatorskich, takich jak Energetyk Gryfino, Czarni Jasło czy Sparta Skalin. Brzeźniak postanowił zbadać także, co determinuje rozpoczęcie uspieranie określonej drużyny (por. rycina 3).

Dlaczego zaczął Pan/Pani wspierać swój ulubiony klub?

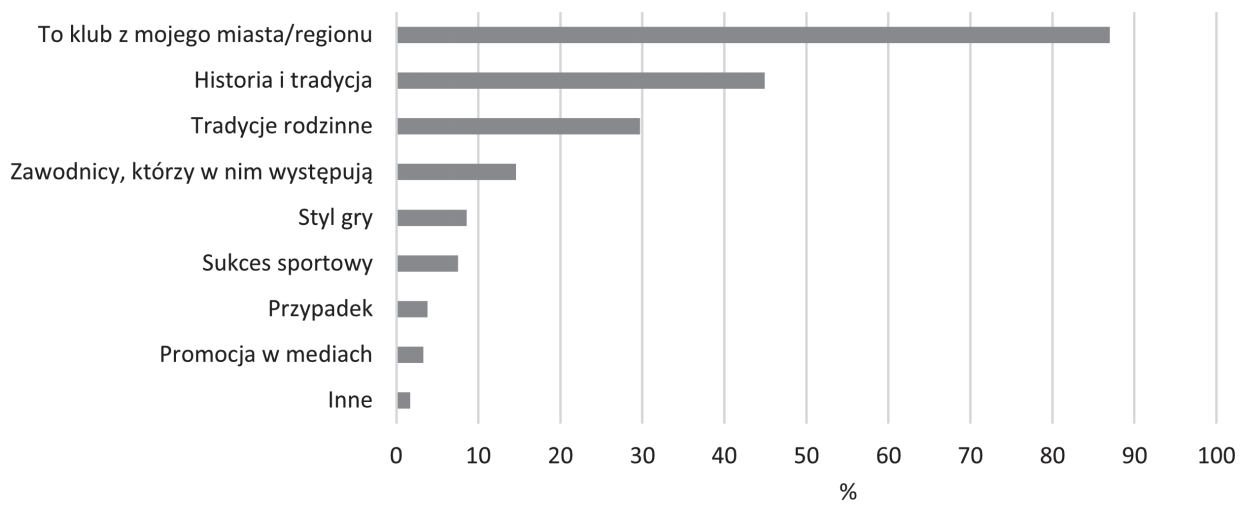

Rycina 3. Motywy rozpoczęcia uspierania danej drużyny

Źródło: opracowanie własne na podstawie M. Brzeźniak, Budowanie świadomości marki w klubie sportowym, Katedra, Gdańsk, 2017, s. 161. 
Na podstawie przytoczonych wyników można stwierdzić, że najważniejszym czynnikiem decydującym o zainteresowaniu konkretną drużyną jest miejsce pochodzenia klubu. Badania Brzeźniaka dowodzą, że polscy kibice piłki nożnej uykazują zainteresowanie amatorskim futbolem. Blisko 90\% ankietowanych uspiera klub ze swojego regionu, zaś niemal co piąta osoba biorąca udział $w$ ankiecie pochodzi ze usi. Zgodnie z „Rocznikiem demograficznym 2019" wydawanym przez Główny Urząd Statystyczny ludność polskich wsi na dzień 31.12.2018 roku wynosiła 15343904 (39,9\% całej populacji)22. Z uwagi na fakt, że większość amatorskich drużyn piłkarskich ma swoją siedzibę na wsii przytoczone dane liczboue mogą potencjalnie dowodzić zainteresowania profilami amatorskich klubów piłkarskich przez internautów.

\section{Pojęcie wizerunku w kontekście klubu piłkarskiego}

Wizerunek (ang. image) według American Marketing Association to: „obraz będący wynikiem postrzegania przez konsumenta produktu, instytucji, marki, biznesu, osoby, który nie musi być spójny z rzeczywistością i faktami” ${ }^{24}$. Jest on więc wynikiem wyobrażeń odbiorcy, które nie muszą mieć związku z prawdą i rzeczywistością. W ujęciu dotyczącym organizacji, stowarzyszeń oraz klubów (niekoniecznie sportowych) wizerunek jest nazywany obrazem utrwalonym w świadomości ludzi, którzy mają z nimi jakiś związek ${ }^{25}$. Inny przykład definicji omawianego terminu stanowi lapidarne ujęcie problematyki przez Adama Figla, który stuierdził że: „wizerunek jest zestawem uyobrażeń, jaki posiadają na temat marki uszyscy odbiorcy jej produktów"26. Zakorzeniony w głowach obraz zrzeszonej grupy ludzi (np. w formie amatorskiego klubu piłkarskiego) ma upływ na zdarzenia behawioralne oraz reakcje osób będących jego odbiorcami (klientów, konsumentów, kibiców itd. 27. Określony rodzaj zachowań bądź postaw tych osób jest uwarunkowany efektem celowych lub przypadkouych działań dotyczących budowania opinii. Z pozycji osoby będącej kreatorem wizerunku jest on syntezą cech (zazuyczaj pozytywnych) tworzących pożądane wyobrażenia oraz postrzeganie podmiotu działalności wizerunkowej.

Wizerunek klubów piłkarskich jest kształtowany w umysłach ludzi, na których bezpośrednio (lojalni kibice, widzowie zmagań sportowych) lub pośrednio (lokalne

22 Główny Urząd Statystyczny, Rocznik Demograficzny 2019, https://stat.gov.pl/obszary-tematyczne/roczniki-statystyczne/roczniki-statystyczne/rocznik-demograficzny-2019,3,13.html (dostęp: 9.12.2019).

${ }^{23}$ Jedynym polskim profesjonalnym klubem piłkarskim mającym siedzibę na usi jest Termalica Bruk-Bet Nieciecza.

${ }^{24}$ Corporate Image, AMA Dictionary, http://www.marketingpower.com/_layouts/dictionary. aspx?dLetter=I (dostęp: 5.12.2019).

${ }_{25}$ W. Budzyński, Public Relations. Strategia i nowe techniki kreowania wizerunku, Poltext, Warszawa 2008, s. 73.

${ }^{26}$ A. Figiel, Etnocentryzm konsumencki. Produkty krajowe czy zagraniczne, Polskie Wydawnictwo Ekonomiczne, Warszawa 2004, s. 77.

${ }^{27}$ G. Białopiotrowicz, Kreowanie wizerunku w biznesie i polityce, Poltext, Warszawa 2009, s. 17. 
społeczeństuo, odbiorcy mediów) oddziałuje. Opinie o danej organizacji (w tym sportowej lub innej) zależą od jej postaw, charakteru, historii, działalności, profilu związanych z nią ludzi oraz wielu innych czynników będących elementami tworzącymi całość, określaną przez anglojęzycznych badaczy terminem image.

Współcześnie wizerunek może być kreowany duutorowo: poprzez autokreację wizerunkową (bezpośrednio przez osobę/organizację, której dotyczy) oraz przez media (wizerunek medialny, często niezależny od działań podmiotu, których dotyczy)28. Zbudowanie image'u wpływającego na wzrost liczby kibiców lub obserwatorów, ukierunkowanego na zwielokrotnianie zysków u sposób świadomy, umożliwia świadoma autokreacja. Wykorzystaniu jej sprzyja środowisko mediów społecznościouych, dających autorowi możliwość kontrolowania treści upublicznionych przekazów. W przeciwieństwie do mediów tradycyjnych, które tworzą wizerunek medialny, niektóre nowe media (np. Facebook lub Twitter) sprzyjają świadomej działalności wizerunkowej. Treści dostępne w telewizji, radiu, gazetach (róunież tych internetouych) są wielokrotnie zamieszczane bez konsultacji z podmiotem, których dotyczą, co może upływać negatywnie na wyobrażenia budowane w umysłach odbiorców. Przykładem tworzenia negatywnego wizerunku medialnego mogą być na przykład doniesienia „Gazety Wyborczej” o zatrzymaniu pseudokibiców klubu GKS Katowice ${ }^{29}$, w których już samo określenie przestępców mianem „kibiców” danego klubu może upłynąć na jego postrzeganie przez odbiorców. Treści wizualne dotyczące klubu piłkarskiego mogą być kreowane poprzez różnorodne formy przekazów, takich jak ulotki, billboardy, banery lub cyfrowy kontent reklamowy zamieszczany w internecie (np. filmy wideo) ${ }^{30}$. Badacze uyróżniają trzy podstawowe czynniki, mające upływ na proces postrzegania organizacji, stowarzyszenia lub klubu. Należą do nich sposób prowadzenia działalności, aktywność społeczna (np. wspieranie lokalnych inicjatyw) oraz postępowanie względem społeczności ${ }^{31}$.

\section{Akływność amatorskich klubów piłkarskich w mediach społecznościowych}

Jednym ze sposobów popularyzowania amatorskiego futbolu wśród społeczeństua jest aktyuność nieprofesjonalnych klubów piłkarskich w mediach społecznościouych. Pomimo istnienia szeregu portali wchodzących w skład obszaru social media, polskie

\footnotetext{
${ }_{28}$ A. Szczudlińska-Kanoś, Marketing polityczny w polskim samorządzie regionalnym, „Studia Regionalne i Lokalne" 2009, nr 3, s. 113-130.

${ }^{29}$ M. Pietraszeuski, Sąd: Kibole GieKSy założyli gang. Rozboje, wymuszenia, sutenerstwo, https://katowice.wyborcza.pl/katowice/7,35063,25441095,sad-kibole-gieksy-zalozyli-gang-rozboje-wymuszenia-sutenerstwo.html (dostęp: 9.12.2019).

${ }^{30}$ K.G. Corley, P.L. Cochran, T.G. Comstock, Image and the impact of public affairs management on internal stakeholders, „Journal of Public Affairs” 2001, nr 1, s. 53-68.

${ }^{31}$ P. Piotrouski, Chuligani a kultura futbolu $w$ Polsce, Wydawnictwo Naukowe PWN, Warszawa 2012, s. 33.
} 


\section{Mateusz Sobiech}

kluby piłkarskie posiadające status amatorskich wykazują aktywność jedynie u pięciu następujących serwisach:

- Facebook;

- Tuitter;

- Instagram;

- Snapchat;

- YouTube.

Największą aktywność omawianych podmiotów można zaobserwować w portalach Facebook oraz Twitter. Biorąc pod uwagę liczbę osób obseruujących profile amatorskich klubów piłkarskich, możliuym jest wyodrębnienie trzech najpopularniejszych zespołów w tej dziedzinie. Należą do nich Coco Jambo Warszawa, Klub Towarzysko-Sportowy (KTS) Weszło Warszawa oraz Ludowy Zespół Sportowy (LZS) Chrząstawa. Wszystkie wymienione zespoły prowadzą działalność wizerunkową w portalach Facebook oraz Twitter, liczba zaś odbiorców generowanych przez nich treści jest zdecydowanie uyższa na portalu założonym przez Marka Zuckerberga (rycina 4).

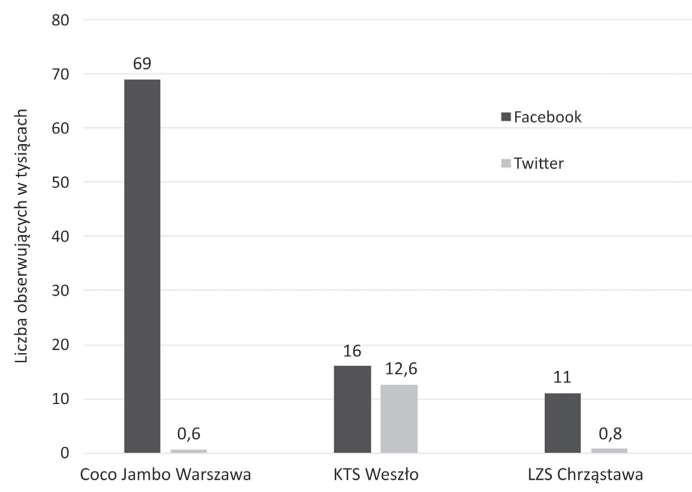

Rycina 4. Trzy najpopularniejsze w serwisach Facebook oraz Twitter polskie amatorskie kluby piłkarskie

Źródło: opracowanie własne (stan z dnia: 3.01.2020).

Wykazaną dysproporcję liczby obserwujących na portalu Facebook oraz mikroblogu, jakim jest Twitter, może uzasadnić między innymi ranking sporządzony przez Hootsuite, czyli najpopularniejszego na świecie narzędzia do zarządzania social media. Zgodnie podanymi przez niego wynikami Facebook w roku 2019 był najpopularniejszym kanałem mediów społecznościouych na śuiecie (ponad 2 miliardy użytkouników)32. W tym samym zestawieniu Twitter zajął szóste miejsce (336 milionów użytkouników), ustępując takim serwisom, jak YouTube, Instagram, Qzone oraz Weibo.

${ }_{32}$ M. Kuchta-Nykiel, 15 najpopularniejszych portali społecznościowych na świecie, https:// socialpress.pl/2018/06/15-najpopularniejszych-portali-spolecznosciouych-na-swiecie (dostęp: 2.12.2019). 


\section{llościowe wyniki badań}

Mimo że spośród analizowanych klubów największą liczbę obserwujących w serwisie Facebook posiada profil Coco Jambo Warszawa, to nie on generuje najwięcej treści. Zdecydowanym liderem w tej kuestii jest KTS Weszło, który przez 2 miesiące opublikował aż 15 razy więcej postóu niż uspomniane Coco Jambo Warszawa oraz ponad trzykrotnie więcej aniżeli LZS Chrząstawa (tabela 1). Sytuacja przedstawia się nieco inaczej u serwisie Twitter, gdzie najwięcej treści publikuje najpopularniejszy z analizowanych profili - KTS Weszło. Warto nadmienić, że twitterouy profil Coco Jambo swój ostatni post opublikował w lutym 2019 roku, co wskazuje na znaczący zanik jego aktyuności w tym serwisie (tabela 2).

Tabela 1. Aktyuność amatorskich klubów piłkarskich u serwisie Facebook u listopadzie i grudniu 2019 roku

\begin{tabular}{|l|c|c|}
\hline \multirow{2}{*}{\multicolumn{1}{|c|}{ Profil }} & \multicolumn{2}{c|}{ Liczba postów (Facebook) } \\
\cline { 2 - 3 } & Listopad & Grudzień \\
\hline Coco Jambo Warszawa & 2 & 0 \\
\hline KTS Weszło & 25 & 5 \\
\hline LZS Chrząstawa & 3 & 6 \\
\hline
\end{tabular}

Źródło: opracowanie własne (stan z dnia: 1.01.2020).

Tabela 2. Aktywność amatorskich klubów piłkarskich w serwisie Tuitter listopadzie i grudniu 2019 roku

\begin{tabular}{|l|c|c|}
\hline \multirow{2}{*}{\multicolumn{1}{|c|}{ Profil }} & \multicolumn{2}{|c|}{ Liczba upisów (Twitter) } \\
\cline { 2 - 3 } & Listopad & Grudzień \\
\hline Coco Jambo Warszawa & 0 & 0 \\
\hline KTS Weszło & 67 & 1 \\
\hline LZS Chrząstawa & 10 & 6 \\
\hline
\end{tabular}

Źródło: opracowanie ułasne (stan z dnia: 1.01.2020).

Warto zauważyć, że liczba upublicznionych postów niekoniecznie przekłada się na liczbę reakcji (polubień, serduszek itp.) użytkouników mediów społecznościouych. O wątpliwej efektyuności stawiania na ilość, a nie jakość zamieszczanych postów, dowodzi przykład KTS Weszło. Mimo że w listopadzie profil tego klubu zamieścił u serwisie Facebook o 20 postów więcej niż u grudniu, suma reakcji na jego aktyuność była większa w grudniu (tabela 3). Nie jest to jednak regułą, co można unioskować z liczby reakcji użytkouników na wpisy KTS Weszło u serwisie Tuitter (tabela 4). Należy nadmienić, że jeden z grudniouych postów KTS Weszło na Facebooku dotyczących spektakularnego transferu jednego z zawodników ${ }^{33}$ zebrał więcej tzw. lajków (ponad 1500) niż łącznie wszystkie listopadowe treści.

${ }^{33}$ Szerzej o tym w dalszej części artykułu. 


\section{Mateusz Sobiech}

Tabela 3. Łączna liczba reakcji na posty amatorskich klubów piłkarskich u serwisie Facebook

\begin{tabular}{|l|c|c|}
\hline \multirow{2}{*}{\multicolumn{1}{c|}{ Profil }} & \multicolumn{2}{c|}{ Łączna liczba reakcji (Facebook) } \\
\cline { 2 - 3 } & Listopad & Grudzień \\
\hline Coco Jambo Warszawa & 2460 & 0 \\
\hline KTS Weszło & 1058 & 1854 \\
\hline LZS Chrząstawa & 157 & 955 \\
\hline
\end{tabular}

Źródło: opracowanie własne (stan z dnia: 1.01.2020).

Tabela 4. Łączna liczba reakcji na wpisy amatorskich klubów piłkarskich u serwisie Tuitter

\begin{tabular}{|l|c|c|}
\hline \multirow{2}{*}{\multicolumn{1}{|c|}{ Profil }} & \multicolumn{2}{|c|}{ Łączna liczba reakcji (Twitter) } \\
\cline { 2 - 3 } & Listopad & Grudzień \\
\hline Coco Jambo Warszawa & 0 & 0 \\
\hline KTS Weszło & 88 & 1425 \\
\hline LZS Chrząstawa & 393 & 121 \\
\hline
\end{tabular}

Źródło: opracowanie własne (stan z dnia: 1.01.2020).

W celu ustalenia efektyuności zamieszczanych treści obliczono średnią reakcję internautów na zamieszczane treści. Na uwagę zasługuje wynik u portalu Facebook profilu Coco Jambo Warszawa, który u tym aspekcie zdecydowanie przewyższa pozostałe kluby (tabela 5).

Tabela 5. Średnia liczba reakcji na post u serwisie Facebook

\begin{tabular}{|l|c|c|}
\hline \multirow{2}{*}{\multicolumn{1}{|c|}{ Profil }} & \multicolumn{2}{c|}{ Średnia liczba reakcji na post (Facebook) } \\
\cline { 2 - 3 } & Listopad & Grudzień \\
\hline Coco Jambo Warszawa & 1230 & 0 \\
\hline KTS Weszło & 42 & 370 \\
\hline LZS Chrząstawa & 52 & 159 \\
\hline
\end{tabular}

Źródło: opracowanie własne (stan z dnia: 1.01.2020).

Tabela 6. Średnia liczba reakcji na upis u serwisie Twitter

\begin{tabular}{|l|c|c|}
\hline \multirow{2}{*}{\multicolumn{1}{|c|}{ Profil }} & \multicolumn{2}{c|}{ Średnia liczba reakcji na wpis (Twitter) } \\
\cline { 2 - 3 } & Listopad & Grudzień \\
\hline Coco Jambo Warszawa & 0 & 0 \\
\hline KTS Weszło & 88 & 21 \\
\hline LZS Chrząstawa & 39 & 20 \\
\hline
\end{tabular}

Źródło: opracowanie własne (stan z dnia: 1.01.2020)

\section{Jakościowe wyniki badań}

Aktywność profilu Coco Jambo Warszawa u serwisie Facebook jest bardzo niska (zaledwie 2 posty przez 2 miesiące), mimo to spotyka się z wysokim odzewem internautów. Jeden z postów, w którym klub ogłasza możliwość zakupu koszulki zespołu, skomentowało 123 użytkowników. Choć część komentarzy ma charakter ironiczny, 
to zdecydowana większość wpisóu wyraża chęć nabycia reklamowanego towaru. Pomimo dużego zainteresowania postem ze strony internautów, profil ani razu nie odpowiedział na żaden z komentarzy. Analogiczna sytuacja miała miejsce u poprzednim opublikowanym poście. Pozwala to wysnuć uniosek, że Coco Jambo Warszawa jest profilem, który u procesie budowania wizerunku nie stawia na interakcję z użytkounikami. LZS Chrząstawa poprzez profil w serwisie Facebook róunież zachęca do nabycia klubouych gadżetów, jednak odzew internautów jest zdecydowanie niższy niż w przypadku Coco Jambo Warszawa. Post, w którym zamieszczono grafikę z dostępnymi u sprzedaży kubkami, smyczami oraz koszulkami klubowymi polubiło zaledwie pięciu użytkouników, zostawiając trzy komentarze. Należy jednak nadmienić, że dużo większą popularnością cieszyły się posty zawierające życzenia z okazji świąt Bożego Narodzenia (95 polubień) oraz nowego roku (105 polubień). LZS Chrząstawa często zamieszcza, zarówno w serwisie Twitter, jak i Facebook, wpisy dotyczące poszukiwania sponsorów. Tego rodzaju aktyuność umożliwiła klubowi między innymi zebranie środków przeznaczonych na modernizację boiska. Ponadto uruchomiła merytoryczną dyskusję użytkowników w komentarzach (rycina 5).

\section{Peter Bielakiewicz Jak ma się remont obiektu na który była zrzutka ? Można jakieś zdjęcia ? Pozdrawiam \\ Like - Reply $\cdot 7 w$ \\ $\hookrightarrow$ View 5 more replies
(ii) Author
LZS Chrząstawa Tak jak Marcin Konieczny mówi tak zostało zrobione. Gdy dokończymy wszystko ładnie to zdjęcia wstawimy \\ Like - Reply - 7w}

Rycina 5. Fragment dyskusji pod jednym z postów profilu LZS Chrząstawa w serwisie Facebook Źródło: https://wuw.facebook.com/permalink.php?story_fbid=3342597435782977 \&id=200333870009365 (dostęp: 3.10.2020).

Działalność wizerunkowa klubu LZS Chrząstawa w serwisie Twitter jest niemal analogiczna do omawianej wcześniej aktywności facebookowej. Klub w obu serwisach zamieszcza te same treści, które zazuyczaj różnią się jedynie formą (Twitter ma ograniczoną liczbę znaków) oraz siłą odzewu (zdecydowanie większa jest na portalu założonym przez Marka Zuckerberga). Warto podkreślić, że róunież na Twitterze w komentarzach wywiązuje się interakcja oparta na konstruktywnej dyskusji z użytkounikami, przynosząca klubowi określone profity (rycina 6). 


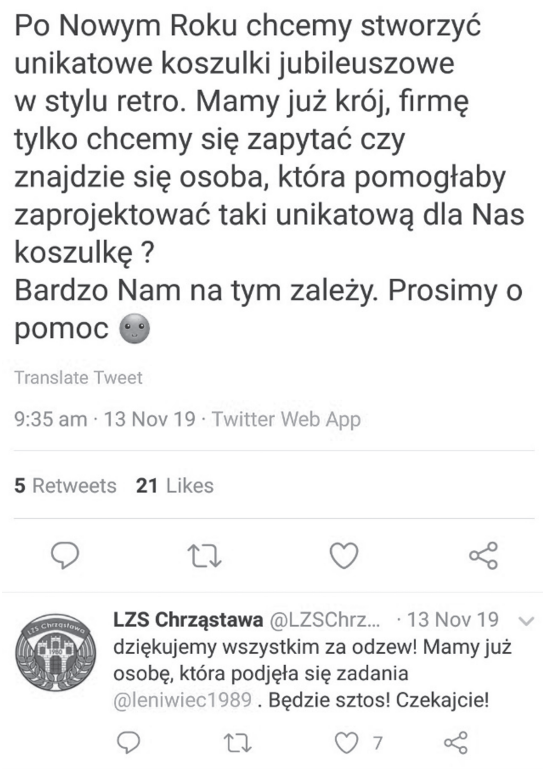

Rycina 6. Wpis oraz uybrany komentarz na profilu LZS Chrząstawa w serwisie Twitter Źródło: https://tuitter.com/lzschrzastawa?lang=en (dostęp: 3.01.2020).

Aktywność KTS Weszło w serwisach Facebook oraz Twitter przypomina strategie budowania wizerunku przez profesjonalne kluby piłkarskie. Zdecydowana większość upisów jest uzupełniona estetyczną grafiką, a ich treść pozwoli odnosić urażenie, że klub występuje w najwyższej klasie rozgrywkowej. Klub często nawiązuje dialog z użytkownikami, zaś o dużej liczbie zamieszczanych przez nich komentarzy przesądzają między innymi stosowane w postach autoironia i sarkazm. Profil KTS Weszło często zamieszcza profesjonalną grafikę z syluetką zawodnika, niemal natychmiast po każdym zdobytym przez niego golu. W ten sam sposób swój wizerunek budują najpopularniejsze kluby Europy. Na tym poziomie rozgrywkowym (A-klasa) jest to zjawisko niespotykane - należy nadmienić, że w przypadku innych klubów sam wynik meczu niejednokrotnie pojawia się $\mathrm{w}$ internecie dopiero kilka godzin po zakończonym spotkaniu. Wartym odnotowania jest jeden z grudniouych postów KTS Weszło, w którym klub oświadczył, że jeden z zawodników został wypożyczony do grającego w 1. Lidze Radomiaka Radom ${ }^{34}$. Nigdy wcześniej w polskim futbolu żaden z piłkarzy nie przeszedł bezpośrednio z siódmej do drugiej klasy rozgrywkowej. Poza dużą skalą zainteresowania innych mediów tym wpisem, zamieszczona treść odnotowała wysoką liczbę komentarzy oraz udostępnień, biorąc pod uwagę obszar amatorskiego futbolu w mediach społecznościowych. Jego autor rozpoczął tym samym internetowy dyskurs dotyczący tak zwanych ukrytych talentów występujących w amatorskich zespołach piłkarskich.

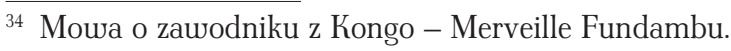




\section{Wnioski i dyskusja}

Bazując na wynikach przeprowadzonych badań można stwierdzić, że cel pracy, tj. prezentacja oraz analiza wizerunku amatorskich klubów piłkarskich w mediach społecznościowych, został osiągnięty. Ponadto udało się ustalić odpowiedzi na postawione pytania badawcze oraz zweryfikować postawione hipotezy. Badania wykazały małą częstotliwość zamieszczanych wpisów. W serwisie Facebook trzy najpopularniejsze amatorskie kluby piłkarskie przez okres dwóch miesięcy opublikowały 41 postów (średnia: 0,67 posta na dzień). Wynik wydaje się niewielki, zułaszcza biorąc pod uwagę treści generowane przez profesjonalne kluby sportowe (w zdecydowanej większości generują co najmniej kilka postów dziennie). Amatorskie kluby piłkarskie potrafią osiągać skrajnie różne wyniki w kontekście reakcji użytkouników na zamieszczane treści. Najbardziej popularny post KTS Weszło zebrał ponad 1500 „lajków”, inne zaś nie przekroczyły liczby 10 . Z całą pewnością można stwierdzić, że fani wykazują większe zainteresowanie poprzez serwis Facebook niż Twitter, co potwierdza przykład każdego z analizowanych klubów. Na uwagę zasługuje spora średnia liczba reakcji na grudnioue posty Coco Jambo Warszawa na najpopularniejszym kanale mediów społecznościowych na świecie. Pomimo znikomej aktywności upisy warszauskiej drużyny spotykają się z dużym odzewem użytkowników. Na podstawie analizy komentarzy zawartych pod postami oraz upisami należy stuierdzić, że 66,6\% badanych klubów wchodzi w interakcję z kibicami. Dialog na linii klub-fani odbywa się w komentarzach, zarówno u serwisie Facebook, jak i Twitter. Najczęściej u dyskusję z użytkounikami wchodził profil LZS Chrząstawa, który w większości przypadków udzielał odpowiedzi na zadawane pytania lub reagował emotikonami.

Posty, w których kluby reklamowały dostępne w sprzedaży gadżety klubowe, potuierdziły teorię, że aktywność w mediach społecznościowych pozwala amatorskim klubom piłkarskim na generowanie zysków finansowych. Poza sprzedażą koszulek, kubków, smyczy itd. znaczną część dochodów mogą także stanowić transfery zawodników do zespołów profesjonalnych. Potwierdza to przykład wypromowania w mediach społecznościowych zawodnika KTS Weszło, któremu udało się przenieść do zawodowego klubu sportowego. Powołując się na ten przykład transferu zawodnika, z całą pewnością można potwierdzić słuszność hipotezy, zgodnie z którą uspółcześnie funkcjonowanie amatorskich klubów piłkarskich wynika już nie tylko z pasji, lecz także z powodów biznesowych. Produkcja oraz sprzedaż gadżetów stały się nowym źródłem dochodów w nieprofesjonalnym futbolu, który dzięki mediom społecznościouym ma szansę dotrzeć do dużej grupy odbiorców.

Ponadto badania wykazały, że podczas przerwy zimowej w mediach społecznościouyych spada aktywność amatorskich klubów piłkarskich. Najbardziej oddaje to liczba zamieszczonych tweetów przez KTS Weszło w listopadzie (67) oraz grudniu (1). Wyjątkiem od tej reguły jest jednak przykład LZS Chrząstawy, który opublikował więcej postów u serwisie Facebook podczas przerwy spowodowanej zimą niż u trakcie trwania sezonu. Z przeprowadzonej analizy można wysnuć róunież dodatkowe wnioski. 


\section{Mateusz Sobiech}

Po pierusze, ilość zamieszczanych treści w mediach społecznościouych niekoniecznie przesądza o liczbie reakcji. Po drugie, brak interakcji z fanami w komentarzach nie powoduje ignorancji przez użytkowników. Obie tezy potwierdza przykład Coco Jambo Warszawa, który jest bardzo oszczędny u generowaniu treści, a mimo to cieszy się największą popularnością spośród wszystkich profili amatorskich klubów piłkarskich w serwisie Facebook. Z całą pewnością przedstawione w artykule badania nie uyczerpują tematu. Stanowią początek analizy nowego zjawiska, jakim jest budowanie wizerunku przez nieprofesjonalne drużyny sportowe. Warto, by przyszłe eksploracje tego obszaru zostały objęte większą cezurą czasową, co umożliwi szersze spojrzenie na opisaną problematykę oraz może sprzyjać wyciągnięciu bardziej zaawansowanych wniosków.

\section{Bibliografia}

Babbie E., Badania społeczne w praktyce, Wydawnictuo Naukowe PWN, Warszawa 2019. Baran D., Internet $w$ Polsce [w:] Polski system medialny 1989-2011, red. K. Pokorna-Ignatouicz, Oficyna Wydawnicza AFM, Kraków 2013.

Berelson B., Content analysis in communication research, The Free Press, New York 1952. Białopiotrowicz G., Kreowanie wizerunku w biznesie i polityce, Poltext, Warszawa 2009.

Bridgewater S., Football brands, Basingstoke, Palgrave 2010.

Brzeźniak M., Budowanie świadomości marki w klubie sportowym, Katedra, Gdańsk 2017.

Budzyński W., Public Relations. Strategia i nowe techniki kreowania wizerunku, Poltext, Warszawa 2008.

Corley K.G., Cochran P.L., Comstock T.G., Image and the impact of public affairs management on internal stakeholders, „Journal of Public Affairs” 2001, nr 1, s. 53-68.

Figiel A., Etnocentryzm konsumencki. Produkty krajowe czy zagraniczne, Polskie Wydawnictuo Ekonomiczne, Warszawa 2004.

Fullerton S., Sports marketing, McGraw-Hill, Maidenhead 2009.

Mruk H., Marketing sportowy - teoria i praktyka, Impact Consulting, Poznań 2004.

Panfil R., Zarzadzanie produktem klubu sportowego, Wyższa Szkoła - Edukacja u Sporcie, Warszawa 2004.

Piotrouski P., Chuligani a kultura futbolu w Polsce, Wydawnictwo Naukowe PWN, Warszawa 2012.

Richelieu A., Pons F., Toronto Maple Leafs vs Football Club Barcelona: How Two Legendary Sports Teams Built Their Brand Equity, „International Journal of Sports Marketing \& Sponsorship" 2006, nr 3, s. 79-98.

Robinson S., France A., Comparing sports marketing of amateur team sports to professional team sports, „New Zealand Journal of Applied Business Research” 2011, nr 1(9), s. 47-61.

Szczudlińska-Kanoś A., Marketing polityczny w polskim samorządzie regionalnym, „Studia Regionalne i Lokalne” 2009, nr 3, s. 113-130.

Wann D.L., Branscombe N.R., Sports fans: Measuring degree of identification with their team, „Sports fans: Measuring degree of identification with their team. International Journal of Sport Psychology" 1993, nr 24, s. 6-27.

Waśkouski Z., Zachowania kibiców jako nabywców oferty usługowej klubu sportowego, „Marketing i Rynek” 2010, nr 4, s. 21-15. 


\section{Źródła internetowe}

Główny Urząd Statystyczny, Kultura fizyczna w Polsce w 2016 r., https://stat.gov.pl/obszary-tematyczne/kultura-turystyka-sport/sport/kultura-fizyczna-w-polsce-w-2016-r-,12,1.html (dostęp: 1.12.2019).

Główny Urząd Statystyczny, Rocznik Demograficzny 2019, https://stat.gov.pl/obszary-tematyczne/roczniki-statystyczne/roczniki-statystyczne/rocznik-demograficzny-2019,3,13. html (dostęp: 9.12.2019).

Kuchta-Nykiel M., 15 najpopularniejszych portali społecznościowych na świecie, https:// socialpress.pl/2018/06/15-najpopularniejszych-portali-spolecznosciouych-na-swiecie (dostęp: 2.12.2019).

Pietraszewski M., Są: Kibole GieKSy założyli gang. Rozboje, wymuszenia, sutenerstwo, https://katowice.uyborcza.pl/katowice/7,35063,25441095,sad-kibole-gieksy-zalozyli-gang-rozboje-wymuszenia-sutenerstwo.html (dostęp: 9.12.2019). 